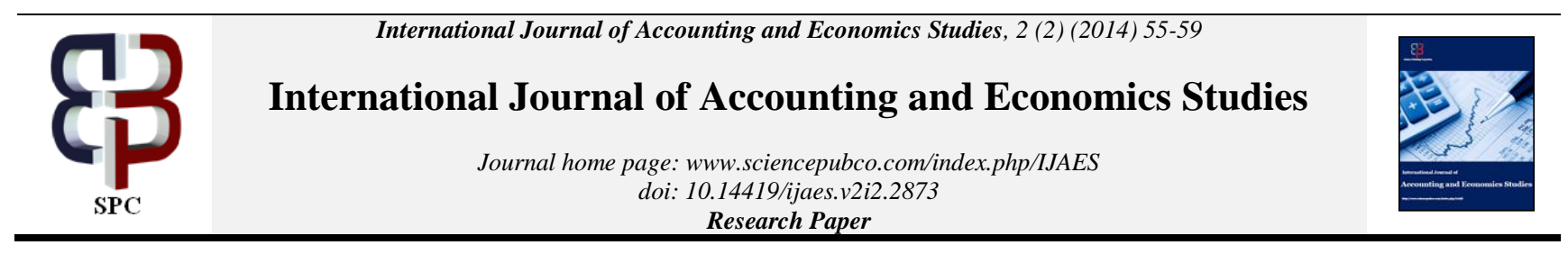

\title{
Effect of increased uncertainty on financial asset holding
}

\author{
Albert Opoku Frimpong \\ Department of Economics, Kwame Nkrumah University of Science and Technology, Kumasi, Ghana \\ E-mail: frimpongao@gmail.com
}

\begin{abstract}
Much is known from theoretical and empirical literature about the relationship between firms' investment decisions and increased uncertainty; thus, firms have preference for liquid assets to capital formation under uncertainty because investment in capital formation is not easily reversible. So, whether uncertainty has effect on financial investment is a moot point to consider. This paper investigates the relationship between financial information and financial asset holding. A model is formulated and empirical evidence provided to throw more light on the relationship. The paper finds that financial information reduces uncertainty regarding investment in financial assets. The paper recommends to financial investors to gather information regarding the investment to minimise the risks associated with losing value for the money invested and also to avoid investment mistakes. Also, the paper finds that financial investors, adopt "wait and see" approach and delay investment with increased uncertainty. Stakeholders should put measures in place to prevent (negative) rumors regarding financial institutions because it cripples financial investment as prospective investors would decrease their investment and wait in order to increase their information about the true state of the market before they make investment. Also, policy makers should ensure macroeconomic stability and safe political environment for the operation of the financial market.
\end{abstract}

Keywords: Financial Assets, Uncertainty, Financial Information, Investment, Interest Rate, Financial Investor

\section{Introduction}

There are a variety of instruments for converting present consumption into future consumption. These include financial assets (debt, shares in firms, pension funds, annuities, mutual funds, insurance policies), real estate, unincorporated business assets, consumer durables (and housing), and even investment in human capital formation (McKnight, 2011). It has long been noted in Economics that there are disparities between the levels of current expenditure and current income over the lifecycle as postulate by the Life Cycle Hypothesis (see Modigliani \& Brumberg, 1954) and the Permanent Income Hypothesis (see Friedman, 1957). The Life Cycle Hypothesis model assumes that a typical person in early adult life is likely to have expenditure above his or her current income leading to dis-saving or debt. This is mostly driven by the need to undertake costly investment in human capital before entering the labour market. Throughout the working life, individuals typically consume less than their disposable income, hence saving some of their current income for future consumption. These models predict several motives for savings which include saving to provide resources to draw upon during retirement and precautionary savings for unexpected expenditure (McKnight, 2011).

In most economies a significant portion of aggregate investment is undertaken by corporate firms who can raise large amounts of risky capital by trading shares, bonds, and other securities (Jones, 2008). Empirical studies show that per capita GDP growth, capital flows, foreign trade, public sector borrowing requirements, external debt, inflation, and interest rate are the main determinants of investment rate, and a well-functioning and developed financial system will efficiently mobilise resources and make them available to firms. The role of finance for investment constitutes a major improvement on the traditional view that domestic saving primar- ily determines domestic investment. This traditional view holds that the level of saving determines the interest rate and thus the

cost of investment, which in turn influences the demand for new capital, and a number of studies have documented a close connection between low investment rates in developing economies and low domestic saving (Ucan \& Ozturk, 2011). Asset markets are the mechanism by which consumption and investment are allocated across time and states of nature (Rudebusch, 2010).

Most people with normal economic status have been able to boost their economic strength and improve livelihood through purchase of shares (Norman, 2012). The act of saving reflects individuals' desire and ability to plan for the future and provides them with a degree of security which can allow them to choose riskier options which may ultimately lead to greater benefits in the long run. Incomes of people are spent, saved, or invested in various instruments in order to reap higher returns in the near future. Savings can provide a deposit for the purchase of a house or to cover the start-up costs of a business. Asset-holding provides individuals with a sense of security that during times of need they would have an asset to draw upon and this has a positive effect on emotional well-being. Assets allow individuals to smooth income by drawing down on savings during times when income falls; which might be due to the loss of employment or when expenditure rises such as following the birth of a baby. There is therefore a strong incentive for individuals to accumulate financial assets since they play a number of important functions in terms of financial well-being (McKnight, 2011).

Paxton (2001) points out that there are benefits from the process of accumulating an asset, in terms of the financial discipline and long term planning process, as well as benefits from having a financial asset which provides security and empowerment from being able to draw on these reserves. McKnight (2011) used longitudinal data from the National Child Development Study to carry 
out a study on over 11, 400 individuals with equal participation of men and women born in 1958 in the United Kingdom to determine the effect of assets held in early adult life on later outcomes. The study explored the impact of holding financial assets and investments at age 23 and age 33 on later outcomes. After applying a battery of techniques to econometric regressions employed for the study, she found that early asset holding has positive effects on later wages, employment prospects, excellent general health, and in reducing malaise.

Investment in Economics means capital formation; the production of new capital assets, including intangible assets such as health and education, which in turn are used in production of the desired goods or services. The term is as well used in Financial Economics to refer to the commitment of money to the purchase of financial instrument so as to gain profitable returns in the form of interest. Examples of financial assets are bonds and stocks and individuals purchase these assets for the purposes of possible higher consumption in the future. An investor is concerned with the choice of assets to include in a portfolio and no matter how risk averse an individual is the optimal solution for him or her is to choose combination of the safe asset and the market portfolio (Mele, 2014).

It is expected that the financial investor would be compensated for the loss of purchasing power, the time value of money, and risk associated with owning the investment. Asymmetric information leads to problems of moral hazard ('incentive effects') and adverse selection ('sorting effects'). Adverse selection means lenders are unable to discriminate between borrowers in terms of the riskiness of their projects; and moral hazard means borrowers undertake higher risk projects with borrowed funds than they would with their own money, since the lender bears part of the cost of failure. The interest rate affects the riskiness of the loan portfolio through moral hazard and adverse selection (Hayes, 2003).

Norman (2012) points out that financial information is imperative in financial investment decision-making. According to Mele (2014), financial securities play a critical role when uncertainty is plugged into the model. Theoretical literature (Cukierman, 1980 Myers \& Majluf, 1984; Baum et al., 2007) predict that firms will delay investment in physical assets to hold liquid assets in the period of increased uncertainty, but little is known about the decision of financial investors when uncertainty augments. The focus of this paper was to investigate the effect of increased uncertainty on financial asset holding. The remainder of the paper is organised as follows: Section 2 surveys literature on interest rate and uncertainty in investment. A model is formulated in Section 3 to determine the relationship between uncertainty and financial asset holding; with Section 4 providing empirical evidence to confirm the model. The last section, Section 5, presents the conclusion of the study.

\section{A survey of theoretical literature on interest rate and uncertainty in investment}

Keynes (1936) puts forward that the marginal efficiency of capital will equal the rate of interest in equilibrium under conditions of perfect certainty. Keynes recognises that liquidity is not an attribute of money alone but also of stock and bond. He argues that the tendency towards speculation reflects liquidity. He considers that for the longer-term reasons the effects of liquidity preference will manifest themselves in a dominant role for the money rate of interest. In addition, Keynes anticipates agency and asymmetric information theory when he suggests that moral hazard may lead lenders of risky debt to charge a premium. The degree of confidence is the weight attached to expectations. The need for a liquidity premium disappears if we abstract from unanticipated changes in expectations. The lender's risk does not exist if the lender and the borrower is/are the same person. If liquidity is the degree to which the value of an asset, measured in any given standard, is independent of changes in the state of long-term expectation, then liquidity premium is the margin required between the marginal efficiencies of the asset and the standard in order to overcome preference for the standard. The size of this margin will depend upon the difference in the degree of confidence with which investors view the prospective yields of the asset and the standard respectively.

Neoclassical theory suggests that high interest rates raise the cost of capital, which reduces the investment rate. McKinnon (1973) and Shaw (1973) offer a theoretical and empirical foundation for the relationship between monetary factors and investment. The assumption of the McKinnon-Shaw hypothesis is that limited access to credit in developing countries forces investors to accumulate enough real balances before they can initiate investment projects; suggesting a positive relationship between real interest rate and investment. Thus, higher interest rates on deposits attract more real balances, which allow the investors to finance more investment. This contradicts the neoclassical view that higher interest rates increase the user cost of capital and thus reduce investment. Government policies affect domestic investment through various channels. One is that government consumption spending may crowd out domestic investment by raising interest rates, resulting in reducing the pool of funds in the markets. This policy of government suggests that individuals will supply their funds to government because of the higher interest rate offered. If firms should offer higher interest rates, we expect that funds would be moved into firms.

Cukierman (1980) and Fuss and Vermeulen (2004) theoretically predicted that an increase in uncertainty would affect the level of investment as well as the timing of investment. They argue that firms, faced with uncertainties regarding the investment, will devote some time to information gathering before choosing a particular investment. They explain that when uncertainty increases, the firm finds it profitable to delay investment decisions even further in order to collect more information. This element, they argue, is particularly important when a project, once started, cannot be reversed easily. In such circumstances it may pay the firm to increase its knowledge about the true relevant distribution before deciding to which project it wants to commit itself. They postulate that firms that find themselves in such a situation will prefer to adopt a "wait and see" approach and delay investment when uncertainty augments, since waiting allows the firm to gather new information on the uncertain future. They conclude that an increase in uncertainty will increase firms' demand for liquid assets while they wait longer in order to increase their information about the true state of the economy before they make investment, thus capital formation. This conclusion in effect suggests that increased uncertainty has no effect on demand for financial assets.

In Lo et al. (2004) and Huang and Wang (2009, 2010), agents receive endowments correlated with the payoff of a risky asset, and the expected return compensates them for the risk that their exposure to that asset will increase. However, none of these studies considers asymmetric information. Focusing on household allocations to risky financial assets, Cardak and Wilkins (2009) studied the portfolio allocation decisions of Australian households using data collected by the Household, Income and Labour Dynamics in Australia (HILDA) Survey. They estimated a model for risky assets holding and found that risky asset holdings are discouraged by labour income uncertainty and poor health. The study, however, failed to consider also the effect of financial information. The interest in modelling investment has also been driven by the desire to forecast, predict, and explain investment for its own sake (Hayes, 2003). Over the time, enormous theories of how investments should be treated and how they have to be analysed have been developed. Theoretical work has provided useful guidance on empirical findings, but the guidance has been incomplete, especially concerning the relationship between uncertainty and financial asset holding. This is because much is known from theoretical and empirical literature about the relationship between firms' investment decisions and increased uncertainty: Researchers (Cukierman, 1980; Hayes, 2003; Fuss \& Vermeulen, 2004; and Baum et al., 2007) have expended considerable effort in trying to understand the relationship between uncertainty and firms' 
capital investment behaviour. Despite the remarkable attention devoted to firms' investment behaviour, little attention is given to individuals' behaviour with regard to financial asset holding when uncertainty augments.

\section{The model}

Consider a financial market with two firms, $i$ and $j$ that float shares. The individual is assumed to distribute his or her income as follows:

$\mathrm{Y}(\mathrm{d})=\mathrm{kx}+\mathrm{pC}$

Where $\mathrm{Y}=$ disposable income, $\mathrm{d}=$ employment status, $\mathrm{x}=$ number of financial securities/shares held, $\mathrm{k}=$ prices of securities, $\mathrm{C}=$ consumer goods, and $\mathrm{p}=$ prices of consumer goods. According to equation (1), the individual divides his or her disposable income between buying securities and consumer goods $(\mathrm{C})$. The disposable income $(\mathrm{Y})$ is assumed to depend on the employment status (d) of the individual; hence, a period of no employment $(\mathrm{d}=0)$ is associated with a zero income $(\mathrm{Y}=0)$ and consequently with zero consumption $(C=0)$ and zero purchase of new securities $(x=0)$. Since $x(Y)$, the higher the income of the individual the greater the number of securities the individual can buy, all other things held constant.

Let $\mathrm{R}$ be the interest rate, thus the returns on investment for holding shares in a firm; $x_{i}$ be the total number of shares held in firm $i$; $x_{j}$ be the total number of shares held in firm $j$, then we have

$\mathrm{R}_{\mathrm{i}} \mathrm{x}_{\mathrm{i}}+\mathrm{R}_{\mathrm{j}} \mathrm{x}_{\mathrm{j}}=\mathrm{r}$

Where $\mathrm{r}$ is the total returns on holding financial assets. If $\left(\mathrm{R}_{\mathrm{i}} \mathrm{x}_{\mathrm{i}}+\right.$ $\left.\mathrm{R}_{\mathrm{j}} \mathrm{x}_{\mathrm{j}}\right)$ is the returns on investment, then $\left[1-\left(\mathrm{R}_{\mathrm{i}} \mathrm{x}_{\mathrm{i}}+\mathrm{R}_{\mathrm{j}} \mathrm{x}_{\mathrm{j}}\right)\right]$ is the risk.

$\left[1-\left(\mathrm{R}_{\mathrm{i}} \mathrm{x}_{\mathrm{i}}+\mathrm{R}_{\mathrm{j}} \mathrm{x}_{\mathrm{j}}\right)\right]=\mathrm{r}_{\mathrm{k}}$

Let $\mathrm{u}=\mathrm{u}\left(\mathrm{x}_{\mathrm{ij}} \ldots \mathrm{x}_{\mathrm{n}}\right)$ be the utility function of the individual. Maximising utility subject to the risk; equation (3);

$\left.\mathrm{L}=\mathrm{u}\left(\mathrm{x}_{\mathrm{ij}} \ldots \mathrm{x}_{\mathrm{n}}\right)+\lambda\left[\mathrm{r}_{\mathrm{k}}-\mathrm{R}_{\mathrm{i}} \mathrm{x}_{\mathrm{i}}-\mathrm{R}_{\mathrm{j}} \mathrm{x}_{\mathrm{j}}\right)+1\right]$

$\mathrm{L}_{\mathrm{i}}=\mathrm{u}_{\mathrm{i}}-\lambda \mathrm{R}_{\mathrm{i}}=0$

$\lambda=u_{i} / R_{i}$

$\mathrm{L}_{\mathrm{j}}=\mathrm{u}_{\mathrm{j}}-\lambda \mathrm{R}_{\mathrm{j}}=0$

$\lambda=\mathrm{u}_{\mathrm{j}} / \mathrm{R}_{\mathrm{j}}$

$\mathrm{L} \boldsymbol{\lambda}=\mathrm{r}_{\mathrm{k}}-\mathrm{R}_{\mathrm{i}} \mathrm{x}_{\mathrm{i}}-\mathrm{R}_{\mathrm{j}} \mathrm{x}_{\mathrm{j}}=0$

Equating equations (5) and (6) gives

$\mathrm{u}_{\mathrm{i}} / \mathrm{u}_{\mathrm{j}}=\mathrm{R}_{\mathrm{i}} / \mathrm{R}_{\mathrm{j}}$

The parameter $=\mathrm{x}^{\mathrm{m}}(\mathrm{R}, \mathrm{x})$ where $\mathrm{m}$ as in $\mathrm{x}^{\mathrm{m}}$ depicts a Marshallian derivation. Now, minimising the risk subject to utility;

$\mathrm{L}=\left[1-\left(\mathrm{R}_{\mathrm{i}} \mathrm{x}_{\mathrm{i}}+\mathrm{R}_{\mathrm{j}} \mathrm{x}_{\mathrm{j}}\right)\right]+\lambda\left(\mathrm{u}^{\mathrm{o}}=\mathrm{u}\left(\mathrm{x}_{\mathrm{ij}} \ldots \mathrm{x}_{\mathrm{n}}\right)\right)$

$\mathrm{L}_{\mathrm{i}}=-\mathrm{R}_{\mathrm{i}}-\boldsymbol{\lambda} \mathrm{u}_{\mathrm{i}}^{\mathrm{o}}=0$

$\lambda=-\mathrm{R}_{\mathrm{i}} / \mathrm{u}_{\mathrm{i}}{ }^{\mathrm{o}}=0$

$\mathrm{L}_{\mathrm{j}}=-\mathrm{R}_{\mathrm{j}}-\lambda \mathrm{u}_{\mathrm{j}}{ }^{\mathrm{o}}=0$

$\lambda=-\mathrm{R}_{\mathrm{j}} / \mathrm{u}_{\mathrm{j}}^{\mathrm{o}}=0$

Equating equations (10) and (12) gives

$\mathrm{u}_{\mathrm{i}} / \mathrm{u}_{\mathrm{j}}=\mathrm{R}_{\mathrm{i}} / \mathrm{R}_{\mathrm{j}}$

The parameter $=\mathrm{x}^{\mathrm{c}}\left(\mathrm{R}, \mathrm{u}^{\mathrm{o}}\right)$; the $\mathrm{c}$ as in $\mathrm{x}^{\mathrm{c}}$ depicts a Hicksian derivation. Equations (8) and (13) imply the marginal utility for holding securities should equal the returns on investment. This suggests that the individual will increase the number of securities held until his or her marginal utility for holding securities equals the interest rate. Put differently, the individual will hold securities until the marginal utility for holding securities equals the returns on investment, interest rate. Thus, if the interest rate is positive, $\frac{\partial x}{\partial R}>0$, we expect the individual to hold more securities until $\mathrm{u}^{\prime}\left(\mathrm{x}_{\mathrm{ij}} \mathrm{x}_{\mathrm{n}}\right)=\mathrm{R}$.

The individual before buying securities at time $t=0$ is assumed to be endowed with or have some information about the investment This endowed information is assumed to be scanty. The individual possesses this information until he or she consciously gathers much information about the investment. Let $\mathrm{I}^{\mathrm{o}}$ be the endowed information, then $\sum_{i=0}^{n} R \mathrm{I}^{\mathrm{o}}$ is the level of endowed information and interest rate available to the individual at a particular point in time. Let $\mathrm{I}^{\mathrm{A}}$ be the acquired information gained through conscious effort to increase the stock of knowledge about the investment. Then $\sum_{i=0}^{n} R \mathrm{I}^{\mathrm{A}}$ is the level of information and interest rate available to the individual at every point in time.

$\left(\mathrm{I}^{\mathrm{O}}<\mathrm{I}^{\mathrm{A}}\right)$

Let $\sum_{i=0}^{n} R \mathrm{I}^{\mathrm{o}}=\sum_{i=0}^{n} R \mathrm{I}^{\mathrm{A}}$

$\mathrm{R}_{\mathrm{o}} \mathrm{I}^{\mathrm{O}}+\sum_{i=1}^{n} R \mathrm{I}^{\mathrm{o}}=\sum_{i=1}^{n} R \mathrm{I}^{\mathrm{A}}+\mathrm{R}_{\mathrm{o}} \mathrm{I}^{\mathrm{A}}$

Equation (14) is arrived at when (i) the individual does not acquire additional information to the endowed information, or (ii) there is no additional information about the financial market or the investment to be added to the endowed information. Thus, $\mathrm{I}^{\mathrm{A}}=0 ; \mathrm{I}^{\mathrm{O}}$ $=I^{A}$. Supposing $R_{0}$ is normalised to $1 ; R_{0}=1$, Then from equation (14),

$\mathrm{I}^{\mathrm{O}}=\sum R \mathrm{I}^{\mathrm{A}}-\sum R \mathrm{I}^{\mathrm{O}}$

$\frac{\partial I}{\partial R}=\mathrm{I}^{\mathrm{A}}-\mathrm{I}^{\mathrm{o}}$

Now from $x^{m}(R, x)$ and $x^{c}\left(R, u^{o}\right)$, assuming $x^{m}$ is adjusted to always equal $x^{c}$, then we have

$\mathrm{x}^{\mathrm{m}}(\mathrm{R}, \mathrm{x})=\mathrm{x}^{\mathrm{c}}\left(\mathrm{R}, \mathrm{u}^{\mathrm{o}^{*}}(\mathrm{R}, \mathrm{x})\right)$

$\frac{\partial x}{\partial R t}=\frac{\partial x}{\partial R}+\frac{\partial x}{\partial u} \times \frac{\partial u}{\partial R}$

$\frac{\partial u}{\partial R}=\frac{\partial u}{\partial I} \times \frac{\partial I}{\partial R}$

But $\frac{\partial I}{\partial R}=\mathrm{I}^{\mathrm{A}}-\mathrm{I}^{\mathrm{o}}$ (thus equation 16)

Substituting equation (16) into equation (18),

$\frac{\partial u}{\partial R}=\frac{\partial u}{\partial I}\left(\mathrm{I}^{\mathrm{A}}-\mathrm{I}^{\mathrm{o}}\right)$

Substituting equation (20) into equation (17),

$\frac{\partial x}{\partial R t}=\frac{\partial x}{\partial R}+\left[\left(\mathrm{I}^{\mathrm{A}}-\mathrm{I}^{\mathrm{o}}\right) \frac{\partial u}{\partial I}\right] \frac{\partial x}{\partial u}$

$\frac{\partial x}{\partial R t}=\frac{\partial x}{\partial R}+\left(\mathrm{I}^{\mathrm{A}}-\mathrm{I}^{\mathrm{o}}\right) \frac{\partial x}{\partial I}<>0$

From equation (20), $\frac{\partial x}{\partial R t}$ indicates the total effect of both interest rate and information on financial asset holding. $\frac{\partial x}{\partial R}$ is the effect of interest rate on financial asset holding; the relationship is positive such that demand for financial asset increases with higher returns on investment, the interest rate; $\frac{\partial x}{\partial R}>0$. If financial assets are normal goods, then $\frac{\partial x}{\partial I}>0$, thus, a positive relationship; implying demand for financial assets increases with much information or reduced uncertainty regarding the investment. If $\mathrm{I}^{\mathrm{A}}>\mathrm{I}^{\mathrm{O}}$ means $\left(\mathrm{I}^{\mathrm{A}}-\mathrm{I}^{\mathrm{O}}\right)>0$, then

$\frac{\partial x}{\partial R t}=\frac{\partial x}{\partial R}+\left(\mathrm{I}^{\mathrm{A}}-\mathrm{I}^{\mathrm{O}}\right) \frac{\partial x}{\partial I}>0$

This implies the individual has gathered much information to make informed decision about the investment. Here, the information effect, $\left(\mathrm{I}^{\mathrm{A}}-\mathrm{I}^{\mathrm{O}}\right) \frac{\partial \mathrm{x}}{\partial \mathrm{I}}$, reinforces the interest rate effect, $\frac{\partial x}{\partial R}$ to increase investment. However, if $\mathrm{I}^{\mathrm{A}}<\mathrm{I}^{\mathrm{O}}$ means $\left(\mathrm{I}^{\mathrm{A}}-\mathrm{I}^{\mathrm{O}}\right)<0$, then $\frac{\partial x}{\partial R t}=\frac{\partial x}{\partial R}+\left(\mathrm{I}^{\mathrm{A}}-\mathrm{I}^{\mathrm{o}}\right) \frac{\partial x}{\partial I}<>0$

That is the sign of $\frac{\partial x}{\partial R t}$ is indeterminate because $\left(\mathrm{I}^{\mathrm{A}}-\mathrm{I}^{\mathrm{o}}\right)<0$ suggesting increased uncertainty regarding the investment. Since information reduces uncertainty, little or lack of it brings about increased uncertainty about the investment and may lead to investment mistakes. In such a situation, it is expected that individuals will wait to gather more information before investing to avoid investment mistakes even though there is a rising returns on investment; $\frac{\partial x}{\partial R}>0$. In econometrics sense, the relationship can be described as follows:

$\mathrm{y}_{\mathrm{t}}=\gamma \mathrm{m}_{\mathrm{t}}+\delta \mathrm{I}_{\mathrm{t}}+\mathrm{e}_{\mathrm{t}}$

where $y_{t}$ is the decision to hold financial asset of interest, $m_{t}$, is a vector of exogenous explanatory variables, $\mathrm{I}_{\mathrm{t}}$ indicates information possessed by the individual regarding assets holding, where $\mathrm{I}_{t}=1$ 
indicates no uncertainty, 0 if otherwise; $(0 \leq \delta \leq 1)$, and $\mathrm{e}_{\mathrm{t}}$ is the error term.

The model shows that, if the individual is allowed to collect information, he or she will usually devote some time to information gathering before choosing a particular investment. The main result is that, when uncertainty increases, the individual will find it profitable to delay investment even further in order to collect more information. Thus, increased uncertainty decreases the current level of investment in financial assets.

\section{Empirical evidence}

Atanasov and Merrick (2010) estimated the slope of the Marshallian demand curve for newly auctioned Federal Home Loan Bank (FHLB) discount notes in USA and investigated the impacts of arbitrage risk and heterogeneity of beliefs on demand elasticity. They used a dataset containing about 2,900 observations of two price quantity pairs: the first from a pre-auction dealer survey and the second from actual auction results. They found strong evidence that demand for FHLB notes was highly elastic and negatively related to proxies for arbitrage risk and heterogeneity of investor beliefs. They found also that demand elasticity dropped by about $50 \%$ during the arbitrage risk and heterogeneity of beliefs. Also, the results of the study showed that asymmetric information affects the slope of a financial asset demand curve and equity markets suffer from larger asymmetric information problems than do government debt markets. They put forward that frictions affecting demand is more intense during periods of financial crisis than during periods of financial stability. Finally, the study found demand elasticity to fall significantly during the credit crisis that began in August 2007.

Mensah (2005) pointed out that as a result of macroeconomic imbalances in the Ghanaian economy in 2001 and 2002, which included severe terms of trade shock of 1999-2000, double digit inflation rates coupled with 15 percent exchange rate depreciation, brought about a higher degree of uncertainty which reflected in the behaviour of participants in the financial sector as savers were unwilling to invest in long-term instruments because of the fear of unstable and high inflation. This situation, he pointed out, made equity investors to demand a high risk premium to compensate them for the risk of providing funds to businesses.

Hastings and Tejeda-Ashton (2008) used data from a survey with an embedded experiment in Mexico's privatised social security system to examine how characteristics, such as education, income, investment experience, and financial literacy impact how workers view investment funds called Afores (Administradoras de Fondos para el Retiro, pronounced Ah-FOR-ay). They found that women and low-income workers were more likely to rely on their employers for information when choosing the afore, while men and internet users were most likely to rely on published information. In addition, translating the impact of information into demand elasticity, the study found changes in information to have very large implied impacts on demand elasticities and on calculations for price-cost margins in the market.

Finally, Norman (2012) investigated whether stock exchange investors consider financial information when deciding to invest in financial assets in Tanzania, using Iringa region as a case study. He grouped the study respondents into Small Investors (SI), Medium Investors (MI), and Large Investors (LI) to form the strata from which samples were drawn for the study. The study revealed that $66.6 \%$ of large investors, $10 \%$ of medium investors, and $0 \%$ of small investors consider financial information when investing; suggesting that the more money invested, the more the sensitivity to risk, hence the need to ensure investment is well taken by gathering much information regarding the investment.

\section{Conclusion}

The paper concludes that increased uncertainty depresses demand for financial assets. The paper found that financial information provides information on the financial market as well as information on financial products to enable the financial investor to make informed investment. Individuals investing in assets such as bonds and stocks should gather information about the investment to make informed investment decision to avoid investment mistake - to be denied of investing in higher yielding and/or safer financial asset as a result of investing in a lower yielding and/or risky financial asset. Informed decision made on investment is vital for minimising the risks associated with losing value for the money invested. Rewarding those with more accurate expectations and punishing those with less accurate expectations reflects the biblical principle of "For everyone who has will be given more; but whoever does not have, even what he has will be taken from him."

The study found evidence similar to firms' capital investment behaviour in that financial investors as well adopt "wait and see" approach and delay investment with increased uncertainty. Stakeholders should put measures in place to prevent (negative) rumors regarding financial institutions because it cripples financial investment as prospective investors would decrease their investment and wait in order to increase their information about the true state of the market before they make investment. Also, since in the period of macroeconomic and political instabilities, financial investors tend to decrease their holding of domestic financial assets, to either invest in foreign liquid assets, policy makers should ensure macroeconomic stability and safe political environment for the operation of the financial market.

\section{Acknowledgement}

The author is grateful to the anonymous reviewers for their helpful comments.

\section{References}

[1] Atanasov, V. and Merrick, J. J. (2010). Determinants of Marshallian demand for financial Assets: Evidence from new issues of Federal Home Loan Bank Debt. http://www.fma.org/Hamburg/Papers/MerrickFHLBDiscountNotesEla sticityFMA.pdf

[2] Baum, F. C., Caglayan, M., Talavera, O. (2007). Uncertainty determinants of firm investment. JEL: E22, D81, C23.

[3] Cardak, B. A. and Wilkins, R. (2009). The determinants of household risky asset holdings: Australian evidence on background risk and other factors. Journal of Banking and Finance.

[4] Cukierman, A. (1980). The Effects of Uncertainty on Investment under Risk Neutrality with Endogenous Information. Journal of Political Economy, Vol. 88, No. 3, pp. 462-475.

[5] Friedman, M. A. (1957). Theory of the Consumption Function. Princeton, NJ, Princeton University Press.

[6] Fuss, C. and Vermeulen, P. (2004). Firms' investment decisions in response to demand and price uncertainty. European Central Bank; Working Paper, No. 347.

[7] Hastings, J. S., Tejeda-Ashton, L. Financial literacy, information, and demand elasticity: survey and experimental evidence from Mexico. National Bureau of Economic Research; Working Paper 14538.

[8] Hayes, M. G. (2003). Investment and finance under fundamental uncertainty. A PhD thesis; University of Sunderland.

[9] Huang, J. and Wang, J. (2009). Liquidity and Market Crashes. Review of Financial Studies, 22, 2607-2643.

[10]Huang, J. and Wang, J. (2010). Market Liquidity, Asset Prices and Welfare. Journal of Financial Economics, 95, 107-127.

[11]Jones, C. (2008). Financial Economics. Routledge Publishers; 2 Park Square, Milton Park, Abingdon, Oxon, OX14 4RN.

[12]Keynes, J. M. (1936). The General Theory of Employment Interest and Money, Vol VII of Collected Writings of John Maynard Keynes, 1973, London, Macmillan. 
[13]Lo, A., Mamaysky, H. and Wang, J. (2004). Asset Prices and Trading Volume under Fixed Transactions Costs. Journal of Political Economy, 112, 1054-1090.

[14]McKinnon, R. (1973). Money and capital in economic development. Washington DC, Brookings Institution.

[15]McKnight, A. (2011). Estimates of the asset-effect: the search for a causal effect of assets on adult health and employment outcomes. Centre for Analysis of Social Exclusion, London School of Economics.

[16]Mele, A. (2014). Lectures on Financial Economics. Centre for Economic Policy Research.

[17]Mensah, S. (2005). Challenges and opportunities facing the financial services industry in a stable macroeconomic environment, Keynote speech delivered at the 8th National Banking Conference of the Chartered Institute of Bankers (Ghana).

[18]Modigliani, F. and Brumberg, R. (1954). Utility Analysis and the Consumption Function: An Interpretation of Cross-Section Data. PostKeynesian Economics.

[19]Myers, S. C. and Majluf, N. S. (1984). Corporate financing and investment decisions when firms have information those investors do not have. Journal of Financial Economics, Vol. 13, 187-221.

[20]Norman, A. S. K. (2012). The usefulness of financial information in capital markets investment decision making in Tanzania: a case of Iringa region. International Journal of Marketing and Technology, Vol 2, issue 8, ISSN 2249-1058.

[21]Paxton, W. (2001). The asset-effect: an overview. Institute for Public Policy Research

[22]Rudebusch, G. D. (2010). Macro-finance models of interest rates and the economy. Working paper; Federal Reserve Bank of San Francisco; Working Paper.

[23] Shaw, E. S. (1973). Financial deepening in economic development. New York: Oxford University Press.

[24]Ucan, O. And Ozturk, O. (2011). Financial determinants of investment for Turkey. Journal of Economic and Social Studies. 